\title{
Translation as an activity of language policy implementation: A myth or reality at the City of Tshwane Metropolitan Municipality
}

\author{
King Costa $(\mathrm{PhD})$ \\ costak@researchglobal.net \\ Keaobaka Omphile Precious Seshoka (PhD) \\ keamab@gmail.com
}

\begin{abstract}
This paper examines how the translation services, as articulated in the language policy and plan of the City of Tshwane Metropolitan Municipality, is used as a language policy implementation strategy and in facilitating public participation. The development of South African official languages is seen as critical in ensuring participatory democracy, where citizens are expected to participate meaningfully to ensure equity of access (South African Municipality Systems Act of 2000). Whereas the City of Tshwane Metropolitan Municipality has done some noticeable work about the promotion of multilingualism and the usage of official languages within the City, lack of visibility of translated documents amongst residents and in its offices needs to be revisited. The key question that this paper asks is 'whether citizens can access or are provided with information they need in the language they understand so that they can take part in the public decision-making in a meaningful way'.
\end{abstract}

The key question is answered by analysing data from the various interviews conducted with the residents from the various regions of the municipality and staff in the language unit of the City of Tshwane Metropolitan municipality and document analysis of the various language documents. Some of the key findings in the paper indicate that translation is not properly used as a tool to facilitate equitable access to municipal information and services. The findings of this paper give policymakers and those tasked with language policy implementation in municipalities proper guidance on how to assess and determine the extent to which translation activities contribute to corpus planning thus ensuring the right of citizens to participate in, and contribute to the social, cultural, economic and political life of South African society.

Key Words: Culture, Diversity \& Inclusion, Economic , Heritage, Language Policy, Political, Service Delivery,Translation 
Table 1. Background to the Problem Detection using PICOC Framework (Costa, 2020)

\begin{tabular}{|c|c|}
\hline Problem & $\begin{array}{l}\text { Language is still a barrier of access to } \\
\text { information for citizens with no or limited } \\
\text { proficiency in English in the City of Tshwane } \\
\text { Metropolitan Municipality (Seshoka, 2013). }\end{array}$ \\
\hline Indicator & $\begin{array}{l}\text { The City of Tshwane has adopted } 8 \text { languages } \\
\text { as official languages; } \\
\text { namely English, Afrikaans, Sepedi, Setswana, } \\
\text { Xitsonga, Tshivenda, IsiZulu, and IsiNdebele, } \\
\text { however after years of implementation of the } \\
\text { language policy, } \\
\text { translation and editing policies in English and } \\
\text { Afrikaans continue to dominate the written } \\
\text { communication and translation of documents in } \\
\text { the municipality (Seshoka, 2013;City of } \\
\text { Tshwane Metropolitan Municipality, 2012). }\end{array}$ \\
\hline Context & $\begin{array}{l}\text { The development of the South African } \\
\text { languages is seen as critical in ensuring } \\
\text { participatory democracy especially in } \\
\text { municipalities, where citizens are expected to } \\
\text { participate meaningfully to ensure equity of } \\
\text { access and participation (Government Gazette, } \\
\text { 2003). }\end{array}$ \\
\hline Objective & $\begin{array}{l}\text { Proper language use and the provision of } \\
\text { translation services can assist in ensuring that } \\
\text { participatory democracy is achieved correctly } \\
\text { thus ensuring that most of the citizens take part } \\
\text { in the municipality processes and gain an } \\
\text { appropriate understanding, as postulated in } \\
\text { Local Government: Municipal Systems } \\
\text { Amendment Act (Government Gazette, 2003). }\end{array}$ \\
\hline Change & $\begin{array}{l}\text { Municipalities must take into consideration the } \\
\text { language usage and } \\
\text { preferences of their residents when engaging } \\
\text { with them (Constitution of the Republic of South } \\
\text { Africa, 1996) }\end{array}$ \\
\hline
\end{tabular}




\section{Framework for Implementation}

In view of the problem and indicators above, the City of Tshwane Metropolitan Municipality requires to implement a responsive framework with clear implementation guidelines for the purposes of answering the research question in this research. Aldrich \& Martinez (2007) postulated the significance and vital role-played by theorists in seeking deeper explanations regarding existing phenomena. A theoretical framework is made up of two distinct words, namely "theory" and "framework". According to Kerlinger (1986), who is considered one of the founding theorists in development of theoretical frameworks, a theory

"a set of interrelated constructs, definitions, and propositions that present a systematic view of phenomena by specifying relations among variables with the purpose of explaining and predicting phenomena.”

On the other hand, Merriam-Webster (2020) defines a framwork as

"a basic conceptional structure (as of ideas)"

In addition to the above, a theory can be defined as a coherent and systematic explanation of a set of relationships to describe the phenomena, based on scientific evidence (Cooper \& Schindler, 2001). According to these scholars, when studying a particular phenomenon, and in this instance, the explication of activities involved in language policy formulation and execution at City of Tshwane Metropolitan Municipality, theory plays a pivotal role in the investigation. In other words, sets of interrelated descriptions, characteristics, and postulations that are presented in pursuit of providing explications and further predictions are scientifically referred to as theories.

In view of the above, a theoretical framework, which is a structure of theories and concepts underpinning this research, builds what can be known as a schematic representation of the entire study, that creates a picture of all the elements of the research trajectory as postulated by Costa (2020). He further asserted the need for researchers to make decisions regarding foundational dynamics of their research inquiry. The decisions include breaking down of concepts from the research questions, to formulation of hypothesis/assumptions, deciding on the philosophical basis for the inquiry and finally integrating the methodological, theoretical and conceptual approaches. 


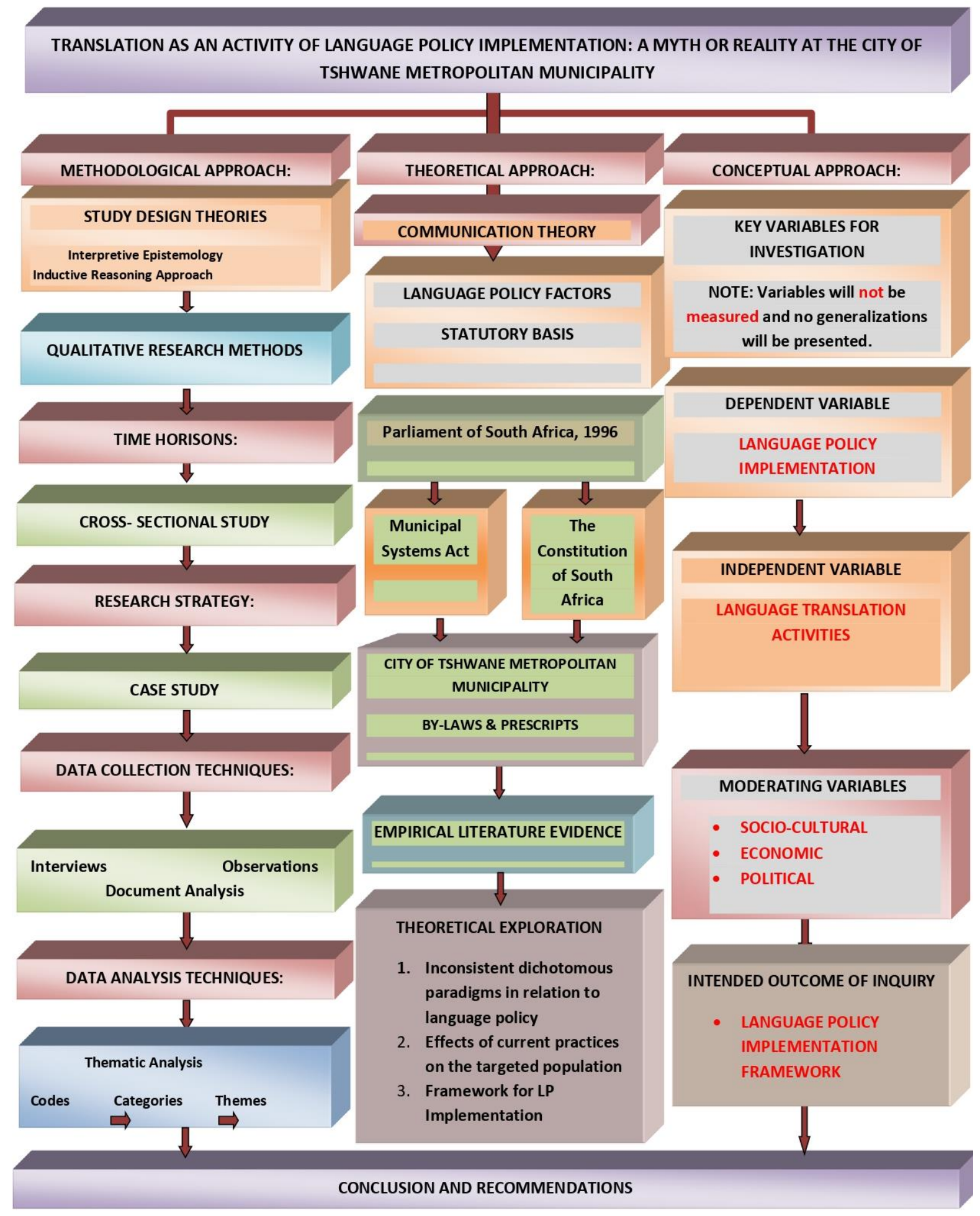

Figure 1: Theoretical Framwork, Adapted to Costa (2020) 
Table 2: Language Policy on Translation : Implementation Framework

\begin{tabular}{|c|c|c|}
\hline Key Variable & Significance & Conceptual Elements \\
\hline Socio-Cultural & $\begin{array}{l}\text { - Language Equity: All people } \\
\text { shall have equal rights to use } \\
\text { their languages (Parliament of } \\
\text { South Africa, 1996). } \\
\text { Multilingualism Heritage: } \\
\text { Enhancement of preservation } \\
\text { and expression of cultural } \\
\text { diversity } \\
\text { Debunking Communication } \\
\text { Barriers: Facilitation of } \\
\text { communication across the } \\
\text { barriers of colour, language, } \\
\text { and religion is a constitutional } \\
\text { and human right in South Africa }\end{array}$ & $\begin{array}{l}\text { - Equal usage of the official } \\
\text { languages of the } \\
\text { municipality in all its } \\
\text { information. } \\
\text { - Language policies and } \\
\text { their implementation ought } \\
\text { to be designed to meet the } \\
\text { needs and interests of all } \\
\text { segments of the population } \\
\text { effectively and equitably } \\
\text { (Kelman, 1971). }\end{array}$ \\
\hline Economic & $\begin{array}{l}\text { - Multidisciplinarism: } \\
\text { Multilingual communication in } \\
\text { conceptualised for economic } \\
\text { participation and enhancement } \\
\text { of municipal communities. } \\
\text { Language-Specific Product } \\
\text { Development: Programmes } \\
\text { for economic development } \\
\text { should be expressed in a } \\
\text { language that enhances } \\
\text { participation across all } \\
\text { conceptual bariers }\end{array}$ & $\begin{array}{l}\text { - Whenever economic } \\
\text { planning, town planning, } \\
\text { and even family planning } \\
\text { are accepted by the } \\
\text { majority of people in the } \\
\text { world today as being } \\
\text { necessary for a healthy and } \\
\text { secure existence, there } \\
\text { ought to be no objection in } \\
\text { principle to language } \\
\text { planning and its } \\
\text { implementation in South } \\
\text { African municipalities } \\
\text { (Alexander, 1991). }\end{array}$ \\
\hline Political & $\begin{array}{l}\text { - Political Literacy: Language } \\
\text { is an important vehicle for } \\
\text { language development and } \\
\text { functionality (Beukes, 2006). } \\
\text { Needs-Based Intergration: } \\
\text { Translation as an activity of } \\
\text { language policy } \\
\text { implementation can be a } \\
\text { facilitator of better } \\
\text { communication between the } \\
\text { government and its citizens } \\
\text { and between people. } \\
\text { Service Delivery: Language } \\
\text { and translation are essential } \\
\text { in improving service delivery } \\
\text { and government } \\
\text { communication with its } \\
\text { residents. }\end{array}$ & $\begin{array}{l}\text { - Language policy } \\
\text { implementation } \\
\text { strategies should be based } \\
\text { on advancing the interests } \\
\text { of the majority of all South } \\
\text { Africans and should reach } \\
\text { all levels of our society } \\
\text { (Alexander, 1991). }\end{array}$ \\
\hline
\end{tabular}




\section{REFERENCES}

Aldrich, H. E. \& Martinez, M. A., 2007. Many are called, but few are chosen: An evolutionary perspective for the study of entrepreneurship. In: Entrepreneurship. s.l.:Springer, p. 293-311.

Alexander, N., 1991. Language policy and national unity in South Africa/Azania.. s.l.:Buchu Books.

Beukes, A. M., 2006. Looking back on translation and interpreting in South Africa: A useful tool in the efficient management of linguistic diversit. Pretoria: Van Schaik.

City of Tshwane Metropolitan Municipality, 2012. Language policy and plan of city of the Tshwane Municipality, Pretoria: City of Tshwane Metropolitan Municipality.

Cooper, D. R. \& Schindler, P., 2001. Business Research Methods. New York.: McGraw.

Costa, K., 2020. Introduction and Background. [Online]

Available at:

https://www.researchgate.net/publication/340610044 INTRODUCTION AND BACK GROUND?channel=doi\&linkld=5e94c3c1299bf1307997840e\&showFulltext=true [Accessed 18 August 2020].

Government Gazette, 2003. Local Government: Municipal Systems Amendment Act, Cape Town: Parliament of South Africa.

Kelman, H. C., 1971. Language as an aid and barrier to involvement in the National System Can language be planned?. Sociolinguistic theory and practice for developin gnations.

Kerlinger, F., 1986. Foundations of behavioral research. 3rd ed. New York: Holt, Rinehart, and Winston.

Merriam-Webster, 2020. framework. [Online]

Available at: https://www.merriam-webster.com/dictionary/framework

[Accessed 16 August 2020].

Parliament of South Africa, 1996. Constitution of the Republic of South Africa. (1996). Bill of Rights. Accessed November 122013 from http://www.justice.gov.za/legislation/constitution/SAConstitution-webeng-. Cape Town: Parliament of South Africa.

Seshoka, K., 2013. Language Policy and Planning in the City of Tshwane Metropolitan Municipality : The challenges of implementation of, Grahamstown: Rhodes. 